\title{
Effect of nitrogen supply on growth and internal nitrogen cycling within deciduous trees
}

\author{
P. Millard
}

Division of Plant Research, Macaulay Land Use Research Institute, Aberdeen AB9 2QJ, Scotland

\section{Introduction}

Deciduous trees cycle nitrogen $(\mathrm{N})$ internally by remobilising $N$ from senescing leaves into woody tissues, from where it is available for growth of new tissues the following year. Such cycling of $N$ is important as a means of augmenting uptake of soil $\mathrm{N}$, since bud break in the spring can occur when conditions for uptake by the roots are suboptimal and before photosynthesis can provide carbon skeletons for amino acid synthesis. Remobilisation of stored $\mathrm{N}$ can, therefore, be a most important contribution to leaf growth at the start of the growing season (Millard and Neilsen, 1988).

Isotopic $\mathrm{N}$ has been used in several studies to trace the movement of previously assimilated $\mathrm{N}$ to the current year's growth (e.g., Weimbaum and Muraoka, 1986). However, few studies have assessed the magnitude of the storage pools of $N$ in relation to current demands for growth. This paper reports the influence fertiliser $N$ has upon internal $N$ cycling, using $N$ supplied to apple trees grown in sand culture to quantify the proportion of $N$ used for seasonal growth that was taken up by roots and that from internal cycling.

\section{Materials and Methods}

One year old apple trees (Malus domestica Borkh) were planted in sand in April 1987 and watered with nutrient solution throughout the experiments, as described by Millard and Neilsen (1988). In the first experiment, $N$ was supplied as ${ }^{15} \mathrm{NH}_{4}{ }^{15} \mathrm{NO}_{3}(4.98$ atom $\% 15 \mathrm{~N}$ ) in solutions containing either none, $0.8 \mathrm{~mol} \mathrm{~N} \cdot \mathrm{m}^{-3}$ or $8.0 \mathrm{~mol} \mathrm{~N} \cdot \mathrm{m}^{-3}$. Flants were harvested throughout the seasonal growth cycle. In the second experiment, plants were grown throughout 1987 with unlabelled $\mathrm{N}$ supplied at $8.0 \mathrm{~mol} \mathrm{~N} \cdot \mathrm{m}^{-3}$, until 1 September. Thereafter, 3 treatments were applied: withholding all further $\mathrm{N}$, defoliation with no further $N$ or maintenance of the $N$ supply until the dormant trees were transferred to a greenhouse for overwintering (on 1 November). In March 1988, each of these 3 treatments was split into 2 blocks and plants were grown

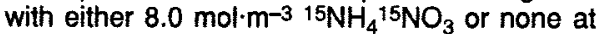
all.

Plants were harvested by removing from the sand and separating into leaves, stems, stem extension growth and roots. All samples were freeze-dried, weighed and analyzed for total $N$ and $15 \mathrm{~N}$ by an ANA-SIRA mass spectrometer. 
The contributions of fertiliser $\mathrm{N}$ and $\mathrm{N}$ remobilised from stems to the $N$ content of the leaves, roots and stem extension growth were calculated as described by Millard and Neilsen (1988).

\section{Results}

The current $N$ supply had no effect upon the amount of $\mathrm{N}$ remobilised from stems or the seasonal growth of new tissues. Increasing the $\mathrm{N}$ supply in the first experiment increased the growth of the new tissues (leaves, roots and stem extension) and their $\mathrm{N}$ content, due to increased uptake of $\mathrm{N}$ (Table I). The amount of $\mathrm{N}$ remobilised was not significantly increased.

Remobilisation of $\mathrm{N}$ stored in stems was particularly important for leaf growth. When the plants were not supplied with any $\mathrm{N}$, all the seasonal growth depended upon internal cycling of $\mathrm{N}$. In these $\mathrm{N}$-deficient plants, leaf growth ceased after 26 June and thereafter $N$ was transferred from the leaves to the roots, which continued to grow throughout the experiment. In contrast, the plants supplied with $8.0 \mathrm{~mol}$ $\mathrm{N} \cdot \mathrm{m}^{-3}$ showed no decrease in the amount of remobilised $\mathrm{N}$ recovered in their leaves after 26 June, so that at the final harvest on 1 September, the proportion of the $N$ remobilised from stems that was recovered in the leaves of the unfertilised plants was 0.51 , compared with 0.76 for the plants fertilised with $8.0 \mathrm{~mol} \mathrm{~N} \cdot \mathrm{m}^{-3}$.

In addition to the spring remobilisation of stored $\mathrm{N}$, internal cycling also involves the storage of $N$ in woody tissues in the autumn. When plants were defoliated on 1 September 1987 in the second experiment, before leaf senescence had started, their leaves contained $224 \pm 8.8 \mathrm{mg}$ $\mathrm{N} \cdot$ plant $^{-1}$. Plants given no $\mathrm{N}$ in the autumn showed typical leaf senescence and by 1

Table I. The effect of $\mathrm{N}$ supply on the remobilisation and uptake of $\mathrm{N}$ used for the growth of new tissues (leaves, stem extension and roots) in experiment 1 by 1 September.

\begin{tabular}{lcccc}
\hline N supply & $\begin{array}{l}\text { Weight } \\
\left(g \cdot \text { plant }^{-1}\right)\end{array}$ & $\begin{array}{l}\text { N content } \\
\left(m g \cdot \text { plant }^{-1}\right)\end{array}$ & $\begin{array}{l}\text { N remobilised } \\
\left(m g \cdot \text { plant }^{-1}\right)\end{array}$ & $\begin{array}{c}\text { N uptake } \\
\left(\text { mg.plant }^{-1}\right)\end{array}$ \\
\hline 0 & 8.1 & 62 & 62 & 0 \\
$0.8 \mathrm{~mol} \mathrm{~N} \cdot \mathrm{m}^{-3}$ & 9.8 & 118 & 64 & 54 \\
$8.0 \mathrm{~mol} \mathrm{~N} \cdot \mathrm{m}^{-3}$ & 15.4 & 392 & 73 & 319 \\
Standard error & 2.47 & 38.2 & 8.1 & 43.3 \\
\hline
\end{tabular}

Table II. The effect of autumn $\mathrm{N}$, defoliation and spring $\mathrm{N}$ on the remobilisation and uptake of $\mathrm{N}$ for the initial spring growth of leaves in experiment 2.

\begin{tabular}{|c|c|c|c|c|}
\hline \multicolumn{2}{|l|}{ Treatment } & \multirow{2}{*}{$\begin{array}{l}\text { Leaf } N \text { content } \\
\left.\text { (mg.plant }{ }^{-1}\right)\end{array}$} & \multirow{2}{*}{$\begin{array}{l}\text { Remobilised N } \\
\left(\text { mg plant }^{-1}\right)\end{array}$} & \multirow{2}{*}{$\begin{array}{l}\text { Uptake of N } \\
\text { (mg.plant }{ }^{-1)}\end{array}$} \\
\hline autumn 1987 & spring 1988 & & & \\
\hline $8.0 \mathrm{~mol} \mathrm{~N} \cdot \mathrm{m}^{-3}$ & $8.0 \mathrm{~mol} \mathrm{~N} \cdot \mathrm{m}^{-3}$ & 236 & 158 & 78 \\
\hline $8.0 \mathrm{~mol} \mathrm{~N} \cdot \mathrm{m}^{-3}$ & No $\mathrm{N}$ & 152 & 150 & 0 \\
\hline NoN & $8.0 \mathrm{~mol} \mathrm{~N} \cdot \mathrm{m}^{-3}$ & 237 & 146 & 91 \\
\hline NoN & No N & 113 & 112 & 0 \\
\hline Defoliation & $8.0 \mathrm{~mol} \mathrm{~N} \cdot \mathrm{m}^{-3}$ & 154 & 85 & 70 \\
\hline Defoliation & NoN & 97 & 95 & 0 \\
\hline Standard error & & 15.7 & 15.9 & 6.9 \\
\hline
\end{tabular}


November the $N$ contents of their leaves had dropped to $68.4 \pm 4.2 \mathrm{mg}^{\prime}$ plant $^{-1}$, as $\mathrm{N}$ was remobilised out of leaves for overwinter storage. In contrast, the plants which continued to receive $\mathrm{N}$ fertiliser after 1 September showed no visible signs of senescence by 1 November, when their leaves were harvested and found to still contain $133 \pm 7.3 \mathrm{mg} \mathrm{N}$.plant $^{-1}$.

The following spring, plants from each of the 3 treatments were either fertilised with $\mathrm{N}$, or received no $\mathrm{N}$ at all. The provision of $\mathrm{N}$ in the spring had no significant effect upon the amount of $N$ remobilised for the initial growth of leaves, as found in the previous year (Table II). Defoliation of plants in the autumn (thereby preventing transfer of leaf $N$ to the stems for storage) decreased the amount of $\mathrm{N}$ remobilised in the spring for leaf growth. However, provision of an autumnal $N$ supply increased the amount of $\mathrm{N}$ available for remobilisation in the spring and appeared to be equally important as allowing the leaves to senesce in the autumn (Table II). The $\mathrm{N}$ supply in the autumn had no effect on the uptake of $\mathrm{N}$ by the plants fertilised in the spring.

\section{Discussion and Conclusion}

Internal $\mathbf{N}$ cycling within deciduous trees has 2 components: the remobilisation of $\mathrm{N}$ from perennial woody tissues for spring growth and the withdrawal of $\mathrm{N}$ from leaves (and roots) during their senescence. Increases in $\mathrm{N}$ supply had no effect upon the amount of $N$ remobilised from stems for the spring growth of leaves. Other studies have suggested that the current growth of the plant is mainly a function of the initial levels of $N$ reserves, since stored $\mathrm{N}$ is always used for growth, irrespective of the current supply (Tromp and Ovaa, 1973).

In a survey of the $\mathrm{N}$ nutrition of a range of trees grown in the field, Chapin and Kedrowski (1983) showed that trees do not change the proportion of leaf $\mathrm{N}$ retranslocated from leaves prior to their abscission in the autumn. Application of $\mathrm{N}$ in the autumn to the trees grown in pots in the present study delayed leaf senescence, and decreased the transfer of $\mathrm{N}$ from leaves to stems from $156 \mathrm{mg} \cdot$ plant $^{-1}$ to $91 \mathrm{mg}^{\text {plant }}{ }^{-1}$. However, provision of an autumnal $\mathrm{N}$ supply slightly increased the amount of $N$ remobilised to leaves the following spring, suggesting that $N$ uptake in the autumn can be important for providing $N$ for overwinter storge as well as $N$ retranslocated from senescing leaves.

\section{References}

Chapin F.S. Ill \& Kedrowski R.A. (1983) Seasonal changes in nitrogen and phosphorus fractions and autumn retranslocation in evergreen and deciduous taiga trees. Ecology 64, 376-391

Millard P. \& Neilsen G.H. (1989) The influence of nitrogen supply on the uptake and remobilisation of stored $\mathrm{N}$ for the seasonal growth of apple trees. Ann. Bot. in press

Tromp J. \& Ovaa J.C. (1973) Spring mobilisation of protein nitrogen in apple bark. Physiol. Plant. 29, 1-5

Weinbaum S.A. \& Muraoka T.T. (1986) Nitrogen redistribution from almond foliage and pericarp to the almond embryo. J. Am. Soc. Hortic. Sci. $111,224-228$ 